\title{
THE ICE OF THE CENTRAL POLAR BASIN *
}

\author{
By Terence Armstrong
}

\author{
(Scott Polar Research Institute, Cambridge)
}

\begin{abstract}
Recent investigations of the ice of the central polar basin have been largely done by Russians, and some of their results are given here. General characteristics of the ice and of the currents and bathymetry of the area are outlined. Attention is directed to advances in knowledge in two spheres: the effect of currents and local winds on ice drift, and the growth and structure of floes. To illustrate the latter, an explanation of the stratification of a $3 \mathrm{~m}$. vertical section is quoted. In conclusion, the prospects of the work continuing, and of its results being made available, are assessed.
\end{abstract}

Zusammenfassung. Neuzeitliche Untersuchungen des Eises des Zentralpolarbeckens sind hauptsächlich von den Russen unternommen worden, und einige ihrer Resultate werden hier wiedergegeben. Die Hauptkennzeichen des Eises und der Ströme und die Bathymetrie des Gebietes werden auseinandergesetzt. Es wird die Aufmerksamkeit auf Fortschritte in der Kenntnis zweier Sphären gezogen: die Wirkung von Strömungen und Lokalwinden auf das Eistreiben und das Wachsen und die Struktur des Treibeises. Um das letztere zu illustrieren wird eine Erläuterung der Schichtung eines $3 \mathrm{~m}$. vertikalen Durchschnittes angeführt. Als Schlussfolgerung werden die Aussichten für die weiterzuführenden Arbeiten und die daraus erhältlichen Resultate abgeschätzt.

\section{INTRODUCTION}

This paper is concerned only with the central part of the Arctic Ocean, which will be referred to as the central polar basin. This is the region about which least is known. The fringing seas, whose northern boundary follows roughly the continental shelf, have been much more closely investigated, but the key to the behaviour of the ice found in them lies in the central polar basin.

Until twenty years ago knowledge of the ice in the central polar basin was limited to Nansen's investigations in the Fram during her drift across it in $1893-96$, with some additional evidence from the drifts of the feannette in $1879-81$ and the Maud in $1922-24$. The conclusion was that there was a drift across the central polar basin from the vicinity of Bering Strait to the Greenland Sea, and that a piece of ice might take three to five years to cover the whole distance. In the last twenty years however there has been a remarkable increase in the number of observations (see Fig. I, p. 104) : first the spectacular Russian north polar drifting station of $1937-38$ (now referred to as $\mathrm{SP}-\mathrm{I}$ ); then the drift of the trapped Sedov in 1937-40; Cherevichnyy's expedition to the region of the Pole of Relative Inaccessibility in the spring of 194I ; and since 1948, a whole series of parties landing by air at various points in the central polar basin, and staying there anything from a few hours to several years. The short visits were made by the Russian high latitude air expeditions, which have taken place probably every spring since 1948 , and by the American Project Skijump in $195 \mathrm{I}$ and $195^{2}$; the longer visits by the American parties on the ice island $\mathrm{T}-3$ (1952-54 and 1955), and Russian parties occupying drifting station $\mathrm{SP}-2$ (I950-51), SP-3 (1954-55), SP-4 (I954 to the present), $\mathrm{SP}_{-5}\left(\mathrm{I}_{955^{-}} 5^{6}\right)$, and $\mathrm{SP}-6$ ( $195^{6}$ to the present). The recent work, then, has been very largely Russian, and it is because there is always difficulty in becoming aware of Russian work that certain points of interest have been selected for consideration here.

\section{General Characteristics of Floating Ice in the Central Polar Basin and Factors In- FLUENCING ITS BEHAVIOUR}

Virtually the whole of the central polar basin is covered by floating ice all the year round. The term "arctic pack" is sometimes used to describe this body of old and heavy sea ice. In my opinion no such specific term is needed, as the ice here is not different in kind from ice elsewhere; and introduction of the term in the sense proposed by the World Meteorological Organisation, as a subdivision of polar ice with no regional limitation, seems an unnecessary near-synonym to polar ice and would in any case sound odd in the Antarctic. In winter the concentration is always ten tenths, but although there is no open water, the ice is not one immense (and therefore immobile) floe. Movement continues all through the winter. In summer the average concentration is probably between nine and ten tenths; the presence of cracks and leads is noticeable and widespread.

* Substance of a lecture given to the Society on 23 January 1957. 
Little more is known about the distribution than this. On the outer fringes of the basin, towards the continental shelf, a more detailed pattern emerges. It has become clear that each summer certain sea areas remain ice-covered while the ice round about melts. These areas of ice are called in Russian "ice massifs" [ledyanyye massivy], and the writer has suggested that the corresponding English term should be "ice clusters". It will be observed (see Fig. 2, p. 107) that several ice clusters noted by the Russians are salients of the main body of ice occupying the central polar basin, and they reach far enough south to affect shipping. This, of course, is the most immediate practical reason for studying the ice of that basin. Presumably there are more ice clusters on the other side of the basin too, but not enough work has been done yet to make them apparent.

Almost all the ice is sea ice. Icebergs are rare in the central polar basin, but they have been sighted from time to time. It has been assumed that they originate chiefly in Zemlya FrantsaIosifa and Severnaya Zemlya. "Ice islands", a particular sort of tabular iceberg, are found, and seem mostly to have broken from the ice shelf on the north coast of Ellesmere Island. At least four have been seen in the central polar basin, and two have been used as the site of drifting stations. The capacity of ice islands for catching the eye of aviators has led to their position being plotted even when no party was established on them, and they have therefore been useful indicators of ice drift.

Recent work by Worthington ${ }^{2}$ has improved our knowledge of the currents of the central polar basin (see Fig. 3, p. I09). On the basis of dynamic computations of water samples at stations he occupied, he has shown the existence of an anticyclonic eddy north of Alaska, in addition to Nansen's cyclonic system. There is undoubtedly evidence to go well beyond these conclusions now; this has been collected by the Russian drifting stations and has not yet been published, although it is now being worked up.

More remarkable has been the advance in knowledge of the submarine relief. The soundings of the Russian drifting stations and high latitude air expeditions have done much to fill in the almost total blank existing before 1948 (see Fig. 4, p. 109). The main feature discovered was the Lomonosov ridge, running from Ellesmere Island to Novosibirskiye Ostrova (as indeed predicted by Worthington). Knowledge that the central polar basin is divided into an Atlantic and a Pacific sector cannot but increase understanding of the behaviour of the ice. The terms "Atlantic sector" and "Pacific sector" are used advisedly; a tendency among Russians and Americans to speak of "east" and "west" in this connexion is to be discouraged, since "east" to a Russian is "west" to an American.

\section{MOVEment}

The general system of ice drift in the central polar basin is of course controlled by the system of currents of which we have already spoken. Thus the latest Russian map of ice drift (Fig. 5, p. I09), which takes account of much of the recent Russian work, is very similar to Worthington's map of currents. It must be emphasized however that other factors play a large part, and that many exceptions to the general rule are already apparent. I will come to these shortly. There is likely to be a link between the surface currents and the Lomonosov ridge; indeed, it would seem at first glance that the "closed circulation" of the Pacific sector is a direct result of it. But on the other hand $\mathrm{SP}_{-3}, \mathrm{SP}_{-4}$ and $\mathrm{SP}_{-5}$ have drifted right across the ridge (see Fig. I). $\mathrm{SP}-4$ has been particularly interesting, since it appeared for nearly the first two years of drift to be following the "closed circulation". But in the spring and summer of 1956 it gathered speed and crossed over the ridge in the direction of the Greenland Sea. It was no doubt in order to find out more about the "closed circulation" that a proposal was made last spring to put the new station SP-6 on the spot at which $\mathrm{SP}_{-2}$ was evacuated. Unfortunately this did not prove possible, but something like this must be done if the limits of the eddy are to be clarified.

More has been learnt about the speed of drift in the two circulations. Ice in the Atlantic sector is carried from the Laptev and Kara Seas to the Greenland current in two to three years. This is 


\begin{tabular}{cccc}
\multicolumn{1}{c}{$\begin{array}{c}\text { Concentration } \\
\text { (ro-ball scale) }\end{array}$} & I & 5 & \multicolumn{1}{c}{} \\
$\begin{array}{c}\text { Hummockiness } \\
\text { (ro-ball scale) }\end{array}$ & & & \\
I & 0.009 & 0.005 & 0.0025 \\
5 & 0.045 & 0.029 & 0.013 \\
9 & 0.081 & 0.052 & 0.0245
\end{tabular}

Thus a heavily hummocked isolated floe will move at nearly $1 / \mathbf{1} 2$ th of the wind speed, while closely packed level ice will move at $\mathrm{r} / 400$ th of the wind speed. The isobaric drift hypothesis still requires elaboration and refinement, undoubtedly, but there is sufficient confirmation to show that there is much truth in it.

\section{Thickness And Structure}

Particular attention has been paid to the manner and rate of growth and decay. Zubov 5,6 has produced formulae expressing growth in terms of degree-days of frost, and maximum thickness in terms of degree-days of frost and extent of summer thawing. The idea behind the second one is that the extent of winter growth diminishes year by year as the ice gets thicker, and there comes a point at which winter increase is balanced by summer loss. The Russian drifting stations have provided more confirmation of this. The floe which had been occupied by SP-2 in $195^{\circ-} 5^{\mathrm{I}}$ was rediscovered in 1954 at lat. $75^{\circ} 40^{\prime} \mathrm{N}$., long. $176^{\circ} \circ 5^{\prime} \mathrm{W}$., which is close to the point at which it had been first occupied. It had evidently described a circle. The thickness of the floe however was almost exactly the same as it had been three years before- $3 \mathrm{~m}$. (Petrov ${ }^{7}$ ). Americans on $\mathrm{T}-3$ found the same absence of change when they rediscovered in 1955 a floe measured in 1952 (Crary ${ }^{8}$ ). In general, thickness tends to increase with latitude, since the number of degree-days normally increases and the summer melting period decreases. But many exceptions to this tendency have been found.

The same rediscovered camp site also provided confirmation of the supposed manner of growth: that the winter's increase is added to the bottom of the floe, while the summer's loss is taken from the top. The tents and other objects were found standing on pillars of ice (prevented by their presence from melting) $\mathrm{I} \cdot 6$ to $\mathrm{I} \cdot 7 \mathrm{~m}$. high (see Fig. 7, p. 103). The annual loss was thus about $55 \mathrm{~cm}$. (Petrov $\left.{ }^{7}\right)$. The tendency of the tents to rise in the course of one summer had in fact been noted by the expedition (Yakovlev ${ }^{9}$ ), but this was more convincing proof.

Little has yet been published of the investigation of the structure of polar ice. There has been a detailed study of changes of surface topography caused by differential melting of ice of different age (Yakovlev ${ }^{10}$ ); and there has been some American and considerably more Russian work on temperature regime (Yakovlev ${ }^{11}$ ). But perhaps the most interesting contribution is Shumskiy's explanation 12 of the stratification of a $3 \mathrm{~m}$. vertical section he took at $\mathrm{SP}-3$ in July 1954 , when the station was within about roo miles $(\mathrm{r} 60 \mathrm{~km}$.) of the North Pole. Thirteen major layers were distinguished, with finer stratification within them. In Fig. 8 (p. rog) the top four layers (I-4) are called "infiltration ice" (Shumskiy's term indicating ice formed by a particular process of firnification), and are similar in texture to ice near the surface of arctic glaciers. They represent accumulation over the four preceding winters ( $195^{\circ}-5 \mathrm{I}$ to $\left.1953-54\right)$. The stratification is somewhat confused here, due to the distortion produced by melting and melt water. The rest of the section is sea ice (easily distinguishable by its different crystal structure), but the upper half of it has lost much of its salt. The bottom layers $(9-13)$ are therefore taken to be the annual growth corresponding to the years of accumulation. Thus the middle of the section $\left(5^{-8}\right)$ is the oldest part of the floe, being formed sometime before 1950 . Shumskiy puts the age of the floe at $6-7$ years, basing this on the period necessary for the ice to freshen to the extent found in these middle layers. The age could be considerably greater if that part of the floe happened to be the wreckage of an older floe. It ffollows from the presence of the top four layers of "infiltration ice" that the snow line was at sea 
Fig. 3 (top left). Atlantic water circulation in the central polar basin (Worthington ${ }^{2}$ )

Fig. 4 (top right). Submarine relief of central polar basin, I954 (Burkhanor ${ }^{3}$ )

Fig. 5 (bottom left). Ice drift in central polar basin (Burkhanov ${ }^{3}$ ) relatively constant course of drift

-. - episodic course of drift

Fig. 6 (bottom right). Mean pressure distribution with mean course of drifting stations, April-September, I954 (Zubov 5$)$
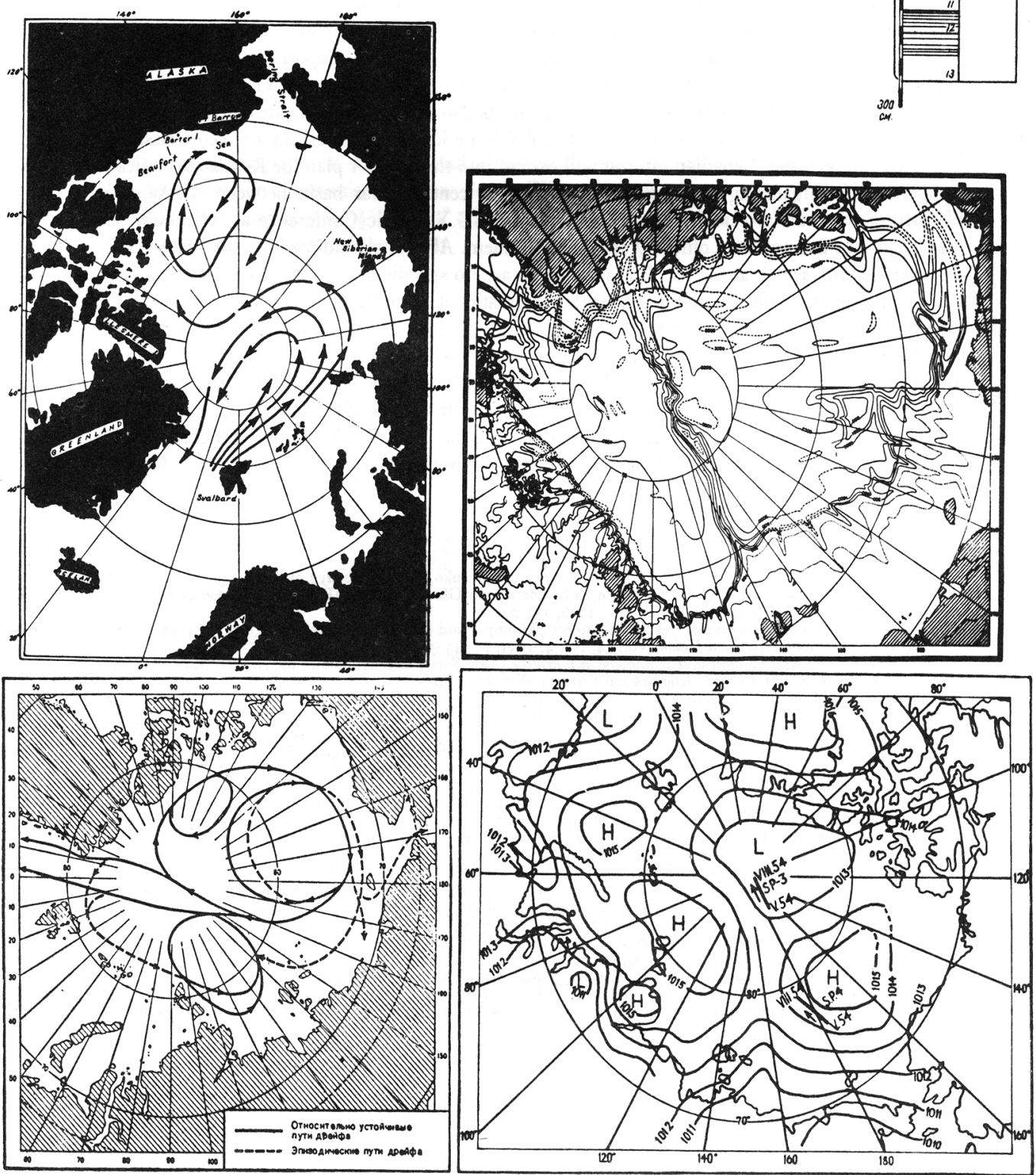

Fig. 8. Stratification of vertical section of sea ice from vicinity of North Pole (Shumskiy12)

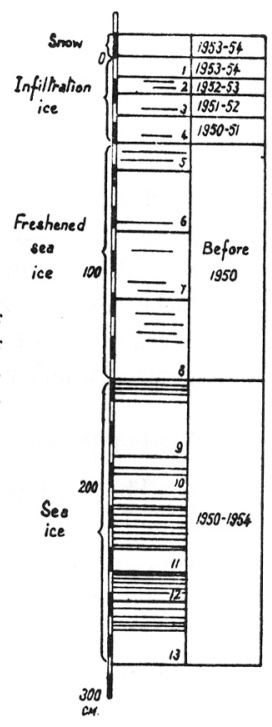


level at this point in the central polar basin, and had been for four years. There has been conflicting evidence on this from other parts of the central polar area, so that we must not generalize from it. This investigation, like a number of others, is only the beginning of a serious attempt to tackle a very large problem, and must serve mainly to emphasize how much remains to be done. Work of a more or less routine nature, like this, must be done at a great many points before valid generalizations can be made.

\section{Future Plans}

There is a likelihood that the near future will see a substantial amount of such work done. The stimulus of the International Geophysical Year is prompting the U.S.S.R. and the U.S.A. to continue investigations. There are to be two Russian drifting stations-the existing SP-6 in the region north of Ostrov Vrangelya and a new one, $\mathrm{SP}-7$, which is to follow the course of $\mathrm{SP}_{-3}$ across the Pole-and one American. Both countries are also likely to deposit automatic weather stations at selected points on the ice (thus obtaining data on the course of drift). The Russian annual high latitude air expeditions are certain also to continue, since they perform the annual relief and re-supply of the drifting stations. There will probably be increased American air reconnaissance of the ice, and possibly Canadian interest will extend into this area. A plan for Russian-American co-operation in organizing alternate flights across the central polar basin between Alaska and Murmansk was put forward by the Russians at the I.G.Y. Arctic Conference at Stockholm in May $195^{6}$, but has not been officially approved by them. All this should lead to more competent observers having a look at sea ice. But since there are no specific sea ice studies included in the I.G.Y. programme, there is not likely to be international co-ordination. The best promise of systematically planned work is from the Russians, both because of their experience and because of the scale of their operations. The all-important question is that of availability of the results. There has been a marked improvement recently of this, with the full results of $\mathrm{SP}-2$ (three volumes) published in $1955^{-56}$, and a number of papers on particular aspects of the later drifts brought out over the last two years. It is to be hoped that the stimulus of the I.G.Y. and the general interest in the work of the drifting stations will secure prompt publication and free availability for the observations.

\section{REF E R E N CES}

I. Karelin, D. B., Volkov, N. A., Zhadrinskiy, V. V., and Gordivenko, P. A. Ledovaya aviatsionnaya razvedka [Ice reconnaissance from the air]. Moscow, Leningrad, Izdatel'stvo Glavsevmorputi [Publishing House of the Chief Administration of the Northern Sea Route], 1946, $152 \mathrm{p}$.

2. Worthington, L. V. Oceanographic results of Project Skijump I and Skijump II in the polar sea, 1951-52. Transactions. American Geophysical Union, Vol. 34 , No. 4, 1953, p. 543-51.

3. Burkhanov, V. F. Novyye sovetskiye issledovaniya $v$ arktike [New Soviet investigations in the Arctic]. Moscow, Geografgiz [Publishing House for Geographical Literature], 1955, 52 p.

4. Zubov, N. N. O dreyfe 1/p "Sedov" (s I sent. I 938 po I fev. I939) [On the drift of the icebreaking ship Sedov (from I September 1938 to 1 February 1939)]. Severnyy Morskoy Put' [Northern Sea Route], No. 14, 1939, p. 5-17.

5. Zubov, N. N. O l'dakh arktiki $i$ antarktiki [On the ice of the Arctic and Antarctic]. Moscow, Moskovskiy Gosudarstvennyy Universitet. Geograficheskiy Fakul'tet [Moscow State University. Geographical Faculty], 1956, 118 . p.

6. Zubov, N. N. L'dy arktiki [Ice of the Arctic]. Moscow, Izdatel'stvo Glavsevmorputi [Publishing House of the Chief Administration of the Northern Sea Route], 1945, 360 p.

7. Petrov, I. G. Fiziko-mekhanicheskiye svoystva i tol'shchina ledyanogo pokrova [Physical and mechanical properties and thickness of ice cover]. In Somov, M. M., ed. Materialy nablyudeniy nauchno-issledovatel'skoy dreyfuyushchey stantsii $1950 / 51$ goda [Observations of the research drifting station of $1950-5 \mathrm{I}$ ], Tom 2, 1955, p. $10_{3}-65$.

8. Crary, A. P. Scientific activities of GRD on Fletcher's ice island. Progress report No. 7, 25 April to 21 fune 1955. Cambridge, Massachusetts, Geophysics Research Directorate, Air Force Cambridge Research Center, 1955.

9. Yakovlev, G. N. Vizual'nyye nablyudeniya nad sostoyaniyem dreyfuyushchego ledyanogo pokrova [Visual observations of the state of drifting ice cover]. In Somov, M. M., ed. Materialy nablyudeniy nauchno-issledovatel'skoy dreyfuyushchey stantsii $1950 / 5 \mathrm{I}$ goda [Observations of the research drifting station of $\left.1950^{-} 5 \mathrm{I}\right]$, Tom $2,1955, \mathrm{p} .6-5 \mathrm{I}$.

ro. Yakovlev, G. N. Nivelirovochnyye raboty po izucheniyu morfologii ledyanogo pokrova [Levelling for the study of morphology of ice cover]. In Somov, M. M., ed. Materialy nablyudeniy nauchno-issledovatel'skoy dreyfuyushchey stantsii $1950 / 51$ goda [Observations of the research drifting station of $1950^{\circ}-5 \mathrm{I}$ ], Tom 2, 1955, p. 52-102.

I I. Yakovlev, G. N. Temperaturnyy rezhim ledyanogo pokrova [Temperature regime of ice cover]. In Somov, M. M. ed. Materialy nablyudeniy nauchno-issledovatel'skoy dreyfuyushchey stantsii 1950/51 goda [Observations of the research drifting station of $\left.1950^{\circ}-5 \mathrm{x}\right]$, Tom 2,1955 , p. $166-350$.

12. Shumskiy, P. A. K izucheniyu l'dov Severnogo Ledovitogo okeana [Study of the ice of the Arctic Ocean]. Vestnik Akademii Nauk SSSR [Messenger of the Academy of Sciences of the U.S.S.R.], No. 2, 1955, p. 33-38. 


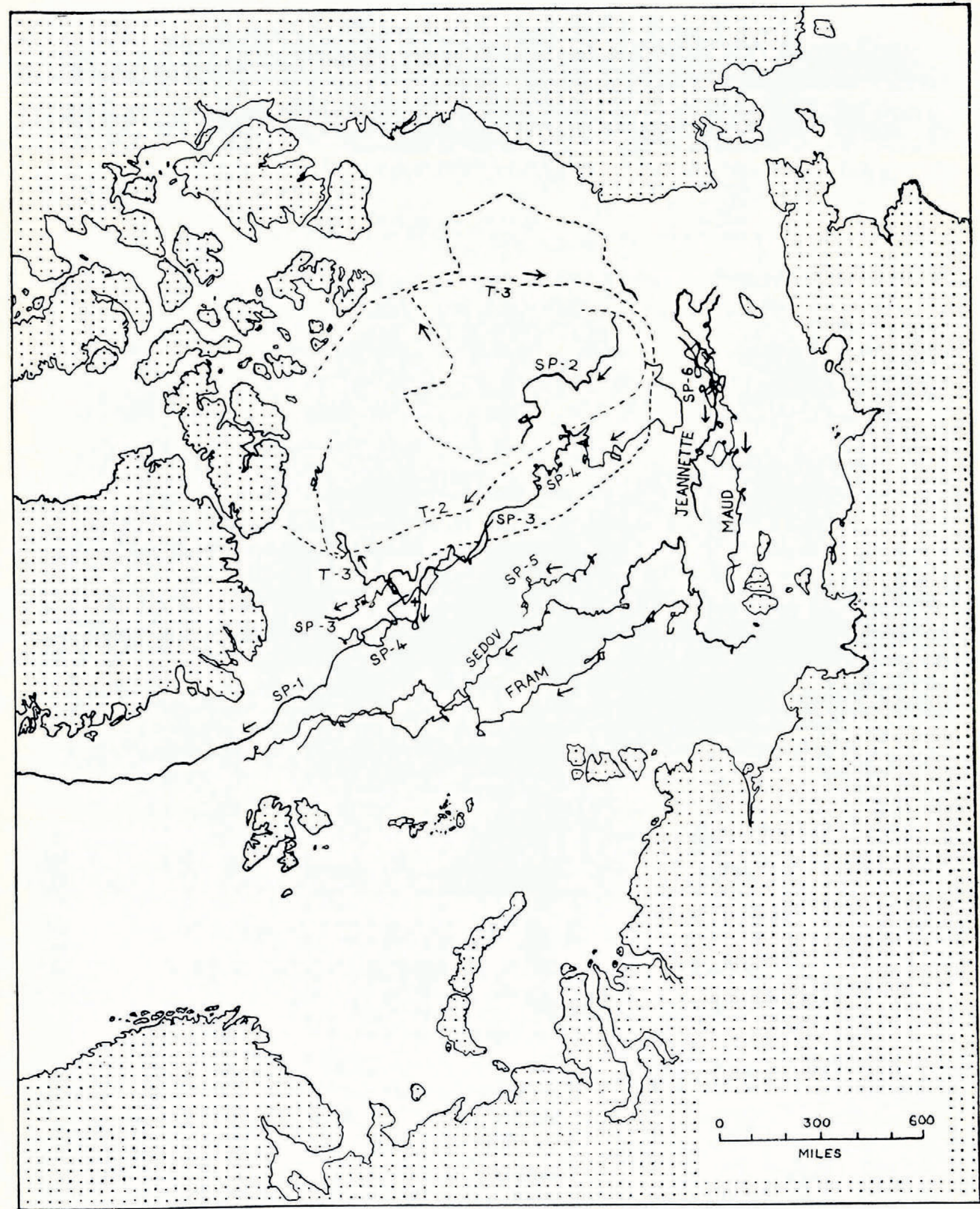

Fig. I. Drifting parties in the central polar basin, $1879-1955$

- manned ships or drifting stations

- - sites of drifting stations when not manned, from air observation. $(300$ miles $=483 \mathrm{~km}$.) 